\title{
New step-by-step algorithms for diagnosis of calcium oxalate urolithiasis based on a qualitative mineralogical composition of calculi
}

\author{
Andrey V. Kustov ${ }^{1-3^{*}}$, Alexander I. Strelnikov², Ashot O. Airapetyan ${ }^{2}$ and Shatlyk M. Kheiderov ${ }^{2}$
}

*Correspondence: kustov@isuct.ru

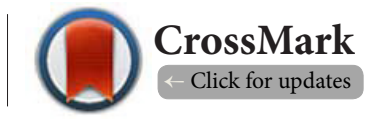

${ }^{1}$ Krestov Institute of Solution Chemistry of RAS, Ivanovo, Russia.

${ }^{2}$ Ivanovo State Medical Academy, Ivanovo, Russia.

${ }^{3}$ Ivanovo State University of Chemistry and Technology, Ivanovo, Russia.

\begin{abstract}
Background: This paper is focused on diagnosis of calcium oxalate renal stones as the most frequent form of urolithiasis in a human society.

Materials and methods: A systematic review of the experimental and clinical studies on calcium oxalate urolithiasis performed during the last two decades has been used to elaborate new programs for diagnosing this frequent disorder.

Results: We have proposed new simple step-by-step algorithms for the diagnostics of calcium oxalate stones which take into account the qualitative mineralogical composition of a calculus and results of the biochemical tests of urine and blood of a patient. The frequency of stone formation, the monohydrate/ dihydrate ratio and amount of minor components have been determined to be the key parameters defining the strategy of a metabolic evaluation.

Conclusions: The concept proposed here is closed on basic measures clear for any physician, not too expensive for a patient and it may be realized in any clinics if the information about the exact mineralogical composition of a calculus is available.
\end{abstract}

Keywords: Calcium-oxalate calculi, qualitative mineralogical analysis, step-by-step diagnostic programs, uric acid derivatives

\section{Introduction}

Urolithiasis remains an important medico-social problem affecting up to $15 \%$ of population of Europe and USA [1-4], more than $70 \%$ of renal stones containing calcium oxalate hydrates $(\mathrm{COH})$ as the major component [2-6]. For many patients this pathological condition induces different complications, reveals a high recurrence rate and step by step leads to chronic renal failure [1,6-8]. Unfortunately, usual measures in domestic clinics mainly devoted to the stone removal are not able to find metabolic disorders causing stone formation. Some useful approaches proposed elsewhere $[1,7,9,10]$ are expensive enough and fail to take into account the qualitative mineralogical composition of calculi, which should be the starting point of all diagnostic and preventive measures [6-8,11].

There are many excellent studies on calcium oxalate urolithi- asis that have been performed for the last twenty years (see, for example [4-8,12-17] and references therein). These results can provide at least, as a first approximation, the relationship between metabolic disorders that caused $\mathrm{COH}$ stone formation and the stone composition. It gives a good opportunity to elaborate new diagnostic algorithms for the $\mathrm{COH}$ stone formers based on the qualitative mineralogical analysis of calculi. Before we start to consider these schemes, there are three important points which should be taken into account. Firstly, we would like to point out that about $75 \%$ of patients could forget about stone recurrent formation by simply changing their lifestyle and dietary habits, providing adequate diuresis and avoiding overweight [8]. Only the remaining $25 \%$ of the stone formers require specific diagnostics and pharmacological intervention to normalize their individual biochemical parameters of blood 
and urine [8]. Secondly, the diagnostic algorithms are to be as lucid as possible for physicians, to be within the standards of medical help and the guidelines proposed. Thirdly, all the measures recommended should be of low cost. With this information in mind and remembering that most of stones are composed of calcium oxalate hydrates $\left(\mathrm{CaC}_{2} \mathrm{O}_{4} \times \mathrm{H}_{2} \mathrm{O}, \mathrm{COM}\right.$; $\mathrm{CaC}_{2} \mathrm{O}_{4} \times 2 \mathrm{H}_{2} \mathrm{O}$, COD) or their mixtures with hydroxyl apatite or uric acid, we have presented here new step-by-step algorithms based on the qualitative mineralogical analysis of calculi.

\section{Materials and methods}

A systematic review of the experimental and clinical studies on calcium oxalate urolithiasis performed during the last two decades $[\mathbf{1}, \mathbf{4 - 8 , 1 2 - 1 7 ]}$ has been used to elaborate new step-by-step approaches for diagnosing and treating this frequent disorder. These clinic and laboratory research have included the quantitative mineralogical analysis of calculi by $\mathrm{X}$-ray diffraction or IR-spectroscopy, electronic microscopy study of their texture and biochemical analysis of blood and urine of patients with $\mathrm{COH}$ renal stones.

\section{Results}

Our approach presented in Figures $\mathbf{1}$ and $\mathbf{2}$ and Tables $\mathbf{1 - 3}$ is mainly based on the experimental results of Daudon et al., $[5,16]$ Pak [12], Trinchieri et al., [15] and general recommendations given elsewhere $[\mathbf{1 , 8 , 1 7 ]}$. These are the step-by-step schemes

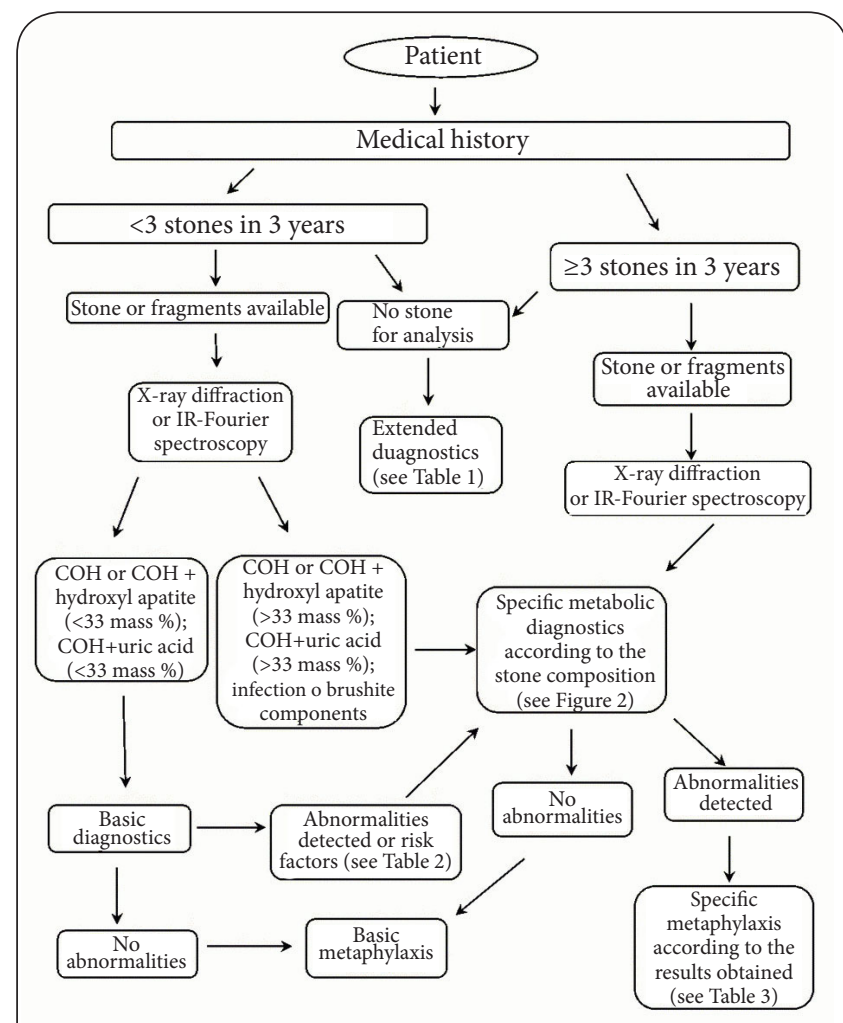

Figure 1. Algorithm of diagnostics of patients based on the calculus composition and the frequency of stone formation.

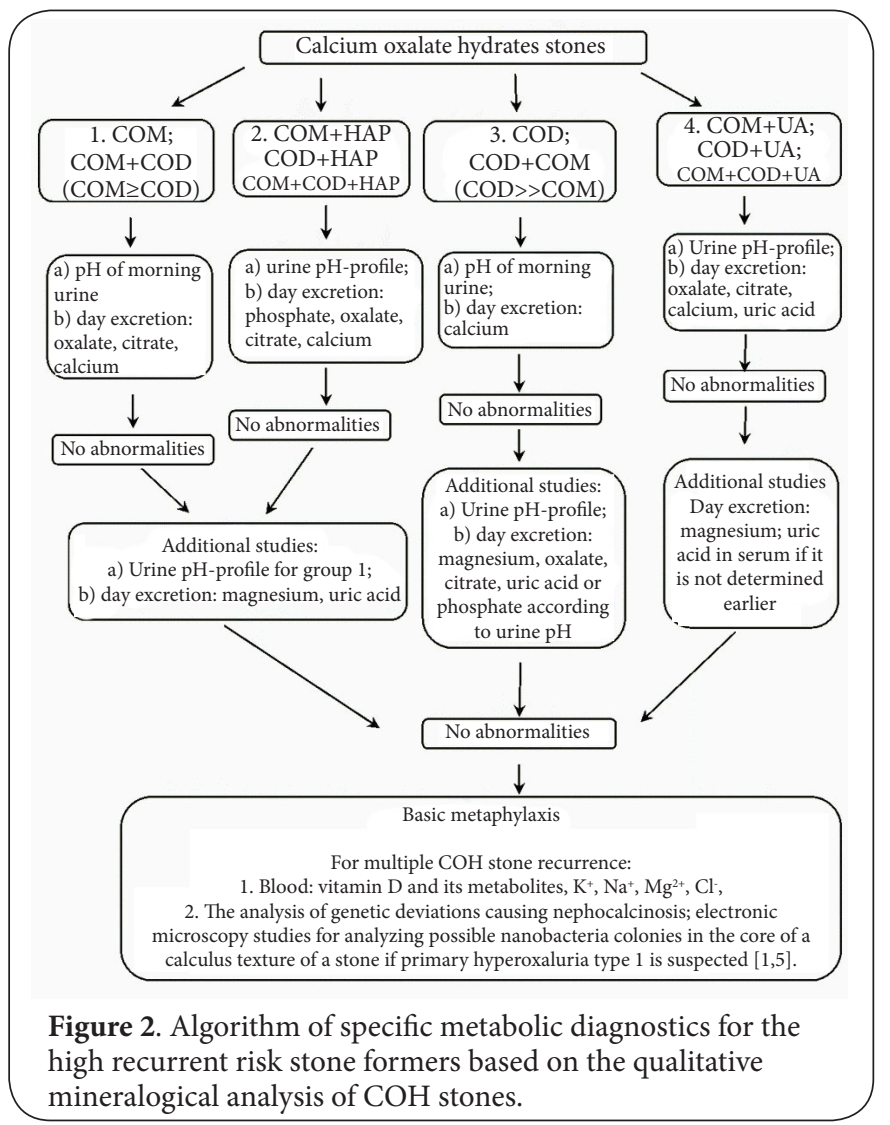

Table 1. Basic and extended diagnostics for patients with $\mathrm{COH}$ stones.

\begin{tabular}{|c|c|}
\hline Basic diagnostics & $\begin{array}{l}\text { Extended diagnostics for } \\
\text { unknown stone composition }\end{array}$ \\
\hline $\begin{array}{l}\text { 1. Medical history (former stone } \\
\text { events, family history, dietary } \\
\text { habits, diuresis etc.) } \\
\text { 2. Ultrasound study of kidneys } \\
\text { and bladder; survey or excretory } \\
\text { urography, if necessary } \\
\text { 3. Biochemical blood analysis: } \\
\text { creatinine, sugar, ionized calcium, } \\
\text { uric acid. }\end{array}$ & $\begin{array}{l}\text { 1. Basic diagnostics. } \\
\text { 2. Urine analysis: } \\
\text { microscopy of morning } \\
\text { precipitate, calcium, } \\
\text { oxalate- and citrate ions. } \\
\text { 3. Non-contrast spiral } \\
\text { computerized tomography for } \\
\text { determination of location and } \\
\text { density of a stone. }\end{array}$ \\
\hline
\end{tabular}

4. Urine analysis: leucocytes,

erythrocytes, $\mathrm{pH}$, specific weight,

nitrite and urine culture, if

necessary.

for diagnosing and treating calcium-oxalate renal stones.

\section{Discussion}

It is widely known that introduction of new options such as shockwave lithotripsy, retrograde and antegrade endoscopic pyelolithotomy into clinical practice has allowed to reach a rapid stone management. These removal techniques became more attractive for many patients than a long-term and routine metaphylactic treatment $[\mathbf{1}, \mathbf{8}]$. However, the high recurrence 
Kustov et al. Clinical Nephrology and Urology Science 2015, http://www.hoajonline.com/journals/pdf/2054-7161-2-3.pdf

doi: $10.7243 / 2054-7161-2-3$

Table 2. Basic metaphylaxis and risk factors requiring specific metabolic diagnostics for $\mathrm{COH}$ stones according to $[1,8,17]$.

\begin{tabular}{|c|c|}
\hline Basic metaphylaxis & Risk factors \\
\hline $\begin{array}{l}\text { 1. Body mass index is to be between } 18 \text { - } \\
25 \mathrm{~kg} / \mathrm{m}^{2} \text { (not appropriate for children). } \\
2 . \text { Diuresis should be not lower than } 2.5 \\
\text { l/day. Circadian drinking or drinking } \\
\text { sufficient amount of neutral beverages } \\
\text { before each urination to reach urine } \\
\text { specific weight of } 1.010 \mathrm{~g} / \mathrm{cm}^{3} \text { or lower is } \\
\text { to be provided. } \\
\text { 3. Balanced diet with predominance } \\
\text { of food containing fiber and sufficient } \\
\text { amount of vegetables is necessary. } \\
\text { Animal protein: }<1 \mathrm{~g} / \mathrm{kg} / \text { day, NaCl: } \\
<5 \text { g/kg/day. Food rich in oxalates and } \\
\text { purines should be limited or avoided. } \\
\text { Calcium containing drugs and dietary } \\
\text { supplements are limited, but normal } \\
\text { consummation of calcium with food of } \\
1 \mathrm{~g} / \text { day is useful to decrease intestinal } \\
\text { oxalate absorption. } \\
4 . \text { Sufficient physical activity to decrease } \\
\text { the stone promoters in urine is to be } \\
\text { supported, stress limitation is welcomed. } \\
5 . \text { For chronic pyelonephritis and } \\
\text { crystalluria application of herbal kidney } \\
\text { collections or drugs on their basis by } \\
\text { several courses during the year is useful. } \\
\text { Six months after the stone removal the } \\
\text { ultrasound investigation and a basic } \\
\text { urine and blood analyses are necessary. }\end{array}$ & $\begin{array}{l}\text { 1. Three of more stone } \\
\text { episodes for the last } \\
\text { three years. } \\
\text { 2. Infection components } \\
\text { such as struvite or } \\
\text { carbonate apatite. } \\
\text { 3. Uric acid derivatives. } \\
\text { 4. Children and } \\
\text { teenagers. } \\
\text { 5. Genetically } \\
\text { determined stone } \\
\text { formation: primary } \\
\text { hyperoxaluria type I, } \\
\text { renal tubular acidosis } \\
\text { type I, cystic fibrosis. } \\
\text { 6. Hyperparathyroidism. } \\
\text { 7. Gastrointestinal } \\
\text { diseases (Crohn's } \\
\text { disease, malabsorption, } \\
\text { colitis, chronic diarrhea, } \\
\text { resection of a part of the } \\
\text { bowel). } \\
\text { 9. Stones in a solitary } \\
\text { kidney. } \\
10 . \text { Nephrocalcinosis. } \\
\text { 11. Residual stones. }\end{array}$ \\
\hline
\end{tabular}

of urolithiasis arose from non-treated metabolic disorders slowly but surely leads to serious organic lesions of kidneys. A significant percentage of such patients is considered to suffer from nephrocalcinosis and chronic renal failure [8]. It is obvious that the cost of treating such life-threatening complications is in times higher than the expenditures for though tedious but really necessary diagnostic and metaphylactic measures [6-8].

Figure 1 shows the diagnostic algorithm closed on the basic metaphylaxis. The first step includes the analysis of patient complaints and a medical history. Then, we have divided patients into two groups. The first group includes patients exhibiting less than three facts of stone formation during the last three years, and the content of minor components in a calculus does not exceed one-third of the stone mass. For this case the cost-saving basic diagnostics and basic metaphylaxis (see Tables 1 and 2) seem to be well justified. If the basic diagnostics reveals the risk factors summarized in Table 2 , the specific metabolic evaluation including corresponding biochemical tests should be subscribed (see Figure 2). This is the case for the second group including the high risk stone formers, when three or more stone episodes during three years are detected or the amount of minor components such as uric acid or hydroxyl apatite exceeds one-third of stone mass.

The incorporation into $\mathrm{COH}$ stones of infected components such as carbonate apatite and struvite or a positive nitrite test testifies that the urine culture investigation should be performed $[\mathbf{1 , 8}]$. If neither the stone nor its fragments are

Table 3. Parameters of blood/urine analysis requiring specific metaphylaxis $[1,6,8,20] \dagger$.

\begin{tabular}{|c|c|c|}
\hline $\begin{array}{l}\text { Parameters } \\
\text { of blood (b) } \\
\text { or urine }(\mathbf{u})\end{array}$ & $\begin{array}{l}\text { Reference ranges and } \\
\text { limits medical } \\
\text { attention }\end{array}$ & Possible diagnosis and common treatment \\
\hline $\mathrm{pH}(\mathrm{u})$ & Constantly $>7.0$ & Urinary tract infection (antibiotic therapy according to the urine culture analysis). \\
\hline $\mathrm{pH}(\mathrm{u})$ & Constantly $>5.8$ & $\begin{array}{l}\text { Renal tubular acidosis type I (load test with } \mathrm{NH}_{4} \mathrm{Cl} \text {, treatment: potassium citrate (KCit) 9-12 g/ } \\
\text { day; thiazide diuretics } 25-50 \mathrm{mg} / \text { day). }\end{array}$ \\
\hline $\mathrm{pH}(\mathrm{u})$ & Constantly $\leq 5.8$ & $\begin{array}{l}\text { Acidic arrest (treatment: KCit 9-12 g/day under the urine } \mathrm{pH} \text { control, bicarbonate mineral } \\
\text { waters). }\end{array}$ \\
\hline Calcium (b) & $\begin{array}{l}>2.6 \mathrm{mmol} / \mathrm{l} \text { (total) } \\
>1.3 \mathrm{mmol} / \mathrm{l} \text { (ionized) }\end{array}$ & $\begin{array}{l}\text { Hypercalcemia, resorptive hypercalciuria (check parathyroid function, treatment - } \\
\text { bisphosphonates, rehydration, sodium chloride). }\end{array}$ \\
\hline Calcium (u) & $\geq 8.0 \mathrm{mmol} / \mathrm{day}$ & $\begin{array}{l}\text { Risk of hypercalciuria. If basic measures do not provide the normal Ca level, it manifests } \\
\text { hypercalciuria (KCit } 9-12 \mathrm{~g} / \text { day under the urine } \mathrm{pH} \text { control of } 6.2-6.8 \text { or sodium bicarbonate } \\
\left(\mathrm{NaHCO}_{3}\right) 1.5 \mathrm{~g} \times 3 \text { times per day). } \\
\text { Hypercalciuria (load test with Ca gluconate; KCit } 9-12 \mathrm{~g} / \text { day under the urine } \mathrm{pH} \text { control of } \\
6.2-6.8 \text {, thiazide diuretics } 25-50 \mathrm{mg} / \text { day; for the absorptive form Ca containing food and } \\
\text { supplements should be restricted). }\end{array}$ \\
\hline Oxalate $(\mathrm{u})$ & $\begin{array}{l}>0.5 \mathrm{mmol} / \text { day } \\
>0.5-0.85 \mathrm{mmol} / \text { day } \\
\text { (secondary) } \\
\geq 1 \mathrm{mmol} / \text { day }\end{array}$ & $\begin{array}{l}\text { Risk of hyperoxaluria. Food low in oxalates. } \\
\text { Moderate hyperoxaluria (oxalate restricted diet, Ca intake } 750-1000 \mathrm{mg} / \text { day to bind oxalate in } \\
\text { the bowel; magnesium of } 200-400 \mathrm{mg} / \text { day under creatinine control). } \\
\text { Probably primary hyperoxaluria type I or II (oxalate in serum, the stone electronic microscopy } \\
\text { analysis or liver biopsy; treatment in special clinics). }\end{array}$ \\
\hline Citrate $(\mathrm{u})$ & $<2.5 \mathrm{mmol} /$ day & Hypocitraturia (KCit or KMgCit 9-12 g/day). \\
\hline Magnesium (u) & $<3 \mathrm{mmol} /$ day & Hypomagnesuria (KMgCit 9-12 g/day or magnesium 200-400 mg/day). \\
\hline Uric acid (u) & $>4 \mathrm{mmol} /$ day & $\begin{array}{l}\text { Hyperuricosuria (foods low in purines; for high uric acid excretion KCit 9-12 g/day and/or } \\
\text { allopurinol } 100 \mathrm{mg} / \text { day; for hyperuricemia - allopurinol 100-300 mg/day). }\end{array}$ \\
\hline
\end{tabular}


removed from a kidney, we recommend the extended diagnostics (see the right column of Table 1) including the computer tomography study for evaluating stone composition [18].

Our algorithm of the specific diagnostics for the high risk $\mathrm{COH}$ stone formers is given in Figure 2. This is also a step-by step approach based on the results of clinical and laboratory research $[5,12,15,16,19]$. These studies have shown that there is a clear relationship between metabolic disorders that caused formation of calculi and their exact mineralogical composition and texture. The analysis of ten thousand patients with $\mathrm{COH}$ renal stones indicates that $\mathrm{COM}$ occurs about twice as frequently as COD, many stones containing both mineralogical phases [15]. In general, stones containing COD as the main component can be correlated with permanent hypercalciuria for almost $90 \%$ of patients. The authors [15] have also pointed out that if the COD content in a mixed COM+COD stone is more than 15 mass\% but lower then COM, it indicates that the stone is often originated by both hypercalciuria and hyperoxaluria. Another important reasons influencing COM stone formation are hypocitraturia and chronic diarrhea leading to urine supersaturation $[12,13,16]$. Finally, the amount of COD less than 10 mass\% appears to testify that hypercalciuria is not the major reason of stone formation [15].

These results are very important, however, we should point out the following. COM as a component of a renal stone can form directly due to the reaction between calcium and oxalate ions in urine or indirectly through the transformation from previously precipitated thermodynamically unstable COD. Hence, there is a probability that for some mixed COM+COD calculi the COD amount detected can be underestimated due to the transformation above. Since COD stones are usually associated with hypercalciuria [15], the estimation of calcium level for such patients is mandatory.

The study of Trinchieri et al., [16] confirms the striking association between hypercalciuria and COD stones, but for the COM formers they are not able to show any higher urinary oxalate excretion in comparison with the COD ones. Thus, we can draw a tentative conclusion that for the COD stone formers it is reasonable to determine at the first stage a calcium level in urine. In contrast, for $\mathrm{COM}$ and $\mathrm{COM}+\mathrm{COD}$ stones arising from several pathological conditions $[15,16]$, the first step of the diagnostic program should include more tests which are summarized for corresponding groups of patients in Figure 2. If all urine and blood parameters are normal at each step, basic metaphylaxis appears to be justified.

When the appreciable amount of uric acid and its derivatives or hydroxyl apatite is found to be incorporated into $\mathrm{COH}$ stones, the special attention should be paid to the $\mathrm{pH}$-profile of urine which can be simply evaluated with pocket $\mathrm{pH}$-meters given to patients for such measurements. These analyses should be performed immediately after each urination. If all urine and blood parameters are again normal (see Figure 2), basic metaphylaxis seems to be recommended. The presence of infected components signifies the necessity to analyze also the urine bacterial culture.

Table 3 shows the internationally accepted values of blood and urine parameters corresponding to various metabolic disorders and common ways for their medical correction $[1,6,8]$. As can be seen, the analysis of the $\mathrm{pH}$-profile of urine during the day provides important information about possible pathological disorders including renal tubular acidosis type I, urinary tract infection or the acidic arrest of urine. Moreover, the constantly acidic $\mathrm{pH}$-profile during the day indicates the high risk of uric acid crystallization. In contrast, when $\mathrm{pH}$ values are constantly larger than six or higher it manifests about the high probability of apatites or brushite crystallization.

If any pathological conditions are not detected, basic metaphylaxis is well justified. For the idiopathic multiple recurrence additional tests given in Figure $\mathbf{2}$ should be prescribed.

The information obtained from the specific diagnostics is to be used to avoid the stone recurrence by correction of metabolic disorders $[1,7,8]$. The widely used drugs for preventing formation of new stones are potassium citrate or potassium/ magnesium citrate mixtures $[\mathbf{4 , 6 , 2 0}]$. They allow to increase urinary $\mathrm{pH}$, magnesium and citrate urine excretion, to bind calcium ions into soluble Ca-citrate complexes to avoid crystallization and dissolve residual fragments [21]. Our very recent study for the group of thirty $\mathrm{COH}$ stone formers has indicated that hypocitraturia is a frequent disorder afflicting about $90 \%$ of patients. It clearly indicates that normalization of the urine citrate level is very important for avoiding the stone recurrence.

\section{Conclusions}

In this paper we have presented new step-by-step diagnostic algorithms for the $\mathrm{COH}$ stone formers based on the qualitative mineralogical analysis of calculi and corresponding biochemical tests. This development is important, because it provides some improvements of the programs used. First, it differentiates patients by the frequency of stone formation and the content of minor components such as uric acid and hydroxyl apatite. Second, the algorithm proposed differentiates for the first time the COM and COD stone formers. Third, it starts from the most important tests providing rather cost-saving diagnostics and treatment. Fourth, the algorithms illustrated in Figures 1 and $\mathbf{2}$ can be presented as a computer program for clinical diagnostics. Fifth and general, this approach is closed on basic metaphylaxis for all the levels of the investigation. Thus, even for false-negative results of biochemical tests, basic metaphylaxis provides at least some of the necessary measures to avoid the stone recurrence.

\section{List of abbreviations}

$\mathrm{COH}$ : Calcium oxalate hydrates

COM: Calcium oxalate monohydrate $\mathrm{CaC}_{2} \mathrm{O}_{4} \times \mathrm{H}_{2} \mathrm{O}$

COD: Calcium oxalate dihydrate $\mathrm{CaC}_{2} \mathrm{O}_{4} \times 2 \mathrm{H}_{2} \mathrm{O}$

\section{Competing interests}

The authors declare that they have no competing interests. 
Kustov et al. Clinical Nephrology and Urology Science 2015, http://www.hoajonline.com/journals/pdf/2054-7161-2-3.pdf

Authors' contributions

\begin{tabular}{|l|c|c|c|c|}
\hline Authors' contributions & AVK & AIS & AOA & SMK \\
\hline Research concept and design & $\checkmark$ & $\checkmark$ & -- & -- \\
\hline Collection and/or assembly of data & $\checkmark$ & -- & $\checkmark$ & $\checkmark$ \\
\hline Data analysis and interpretation & $\checkmark$ & -- & -- & -- \\
\hline Writing the article & $\checkmark$ & $\checkmark$ & -- & -- \\
\hline Critical revision of the article & $\checkmark$ & $\checkmark$ & $\checkmark$ & $\checkmark$ \\
\hline Final approval of article & $\checkmark$ & $\checkmark$ & $\checkmark$ & $\checkmark$ \\
\hline Statistical analysis & -- & -- & -- & -- \\
\hline
\end{tabular}

\section{Acknowledgement}

The financial support of this work by the Russian Foundation for Basic Researches (grant N 15-44-03016-reg) and the "Umnik" program (for AOA) is gratefully acknowledged.

Publication history

EIC: Kevin R. Loughlin, Harvard Medical School, USA.

Received: 17-Jul-2015 Final Revised: 28-Aug-2015

Accepted: 08-Sep-2015 Published: 16-Sep-2015

\section{References}

1. Voschula VI. Urinary stone disease: the etiotropic and pathogenetic treatment. VEVER. Minsk. 2006.

2. Porena $M$, Guiggi $P$ and Micheli C. Prevention of stone disease. Urol Int. 2007; 79 Suppl 1:37-46. | Article | PubMed

3. Ivanovski $O$ and Drueke TB. A new era in the treatment of calcium oxalate stones? Kidney Int. 2013; 83:998-1000. | Article | PubMed

4. Tiselius HG. Metabolic evaluation of patients with stone disease. Urol Int. 1997; 59:131-41. | Article | PubMed

5. Daudon $M$, Bazin D, Andre $G$, Jungers $P$, Cousson $A$, Chevallier $P$, Veron $E$ and Matzen $G$. Examination of whewellite kidney stones by scanning electron microscopy and powder neutron diffraction techniques. J Appl Cryst. 2009; 42:109-115. | Article

6. Preminger GM and Tan YH. Pharmacologic prophylaxis of calcium stones. In Stoller ML and Meng MV (Eds.), Urinary stone disease: the practical guide to medical and surgical management 2007; 269-284. I Book

7. Bichler KH, Lahme C, Mattauch W and Strohmaier WL. Metabolische evaluation und metaphylaxe von harnsteinpatienten. Aktuel Urol. 2000; 31:283-293. | Article

8. Straub M, Strohmaier WL, Berg W, Beck B, Hoppe B, Laube N, Lahme S, Schmidt M, Hesse A and Koehrmann KU. Diagnosis and metaphylaxis of stone disease. Consensus concept of the National Working Committee on Stone Disease for the upcoming German Urolithiasis Guideline. World J Urol. 2005; 23:309-23. | Article | PubMed

9. Tiktinskiy OL and Alexandrov VP. Urolithiasis. 2000.

10. Nitkin DN. Medicine rationale for a correction of metabolic disorders for urolithiasis. MD Thes. Minsk 2005.

11. Schubert G. Urinary stone analysis. In Rao PN, Preminger GN and Kavanagh JP (Eds.), Urinary Tract Stone Disease 2011; 341-353. | Book

12. Pak CY, Poindexter JR, Adams-Huet $B$ and Pearle MS. Predictive value of kidney stone composition in the detection of metabolic abnormalities. Am J Med. 2003; 115:26-32. | Article | PubMed

13. Zuckerman JM and Assimos DG. Hypocitraturia: pathophysiology and medical management. Rev Urol. 2009; 11:134-44. | PubMed Abstract | PubMed Full Text

14. Marangella $M$, Vitale $C$, Bagnis $C$, Bruno $M$ and Ramello $A$. Idiopathic calcium nephrolithiasis. Nephron. 1999; 81 Suppl 1:38-44. | PubMed

15. Maurice-Estepa L, Levillain P, Lacour B and Daudon M. Advantage of zero-crossing-point first-derivative spectrophotometry for the quantification of calcium oxalate crystalline phases by infrared spectrophotometry. Clin Chim Acta. 2000; 298:1-11. | Article | PubMed
16. Trinchieri A, Castelnuovo C, Lizzano R and Zanetti G. Calcium stone disease: a multiform reality. Urol Res. 2005; 33:194-8. | Article | PubMed

17. Türk C, Knoll T, Petrik A, Sarica K, Straub M and Seitz C. Guidelines on urolithiasis. EAU. 2012. I Pdf

18. Sheir KZ, Mansour O, Madbouly K, Elsobky E and Abdel-Khalek M. Determination of the chemical composition of urinary calculi by noncontrast spiral computerized tomography. Urol Res. 2005; 33:99104. | Article | PubMed

19. Bouzidi H, de Brauwere D and Daudon M. Does urinary stone composition and morphology help for prediction of primary hyperparathyroidism? Nephrol Dial Transplant. 2011; 26:565-72. | Article | PubMed

20. Ettinger B, Pak CY, Citron JT, Thomas C, Adams-Huet B and Vangessel A. Potassium-magnesium citrate is an effective prophylaxis against recurrent calcium oxalate nephrolithiasis. J Urol. 1997; 158:2069-73. | Article | PubMed

21. Kustov AV, Shevyrin AA, Strel'nikov AI, Smirnov PR and Trostin VN. Chemolysis of calcium oxalate stones: study in vitro and possible clinical application. Urol Res. 2012; 40:205-9. | Article | PubMed

\section{Citation:}

Kustov AV, Strelnikov AI, Airapetyan AO and Kheiderov SM. New step-by-step algorithms for diagnosis of calcium oxalate urolithiasis based on a qualitative mineralogical composition of calculi. Clin Nephrol Urol Sci. 2015; 2:3. http://dx.doi.org/10.7243/2054-7161-2-3 